\title{
İnguinal Herniasyonun Nadir Bir Nedeni: Mesane Hernisi
}

\section{A Rare Cause of Inguinal Herniation: Bladder Herniation}

\section{Sefa TÜRKOĞLU1 ${ }^{1}$ Cihan BEDEL ${ }^{2}$}

\author{
${ }^{1}$ Uzman Dr. Denizli Devlet Hastanesi, Radyoloji Kliniği, DENIZLİ \\ ${ }^{2}$ Uzman Dr. Sağlık Bilimleri Üniversitesi, Antalya Eğitim ve Araştırma Hastanesi, Acil Tıp Kliniği, Kazım Karabekir Caddesi, 07100, \\ Muratpaşa, ANTALYA
}

\section{Öz}

Mesanenin inguinal hernisi, inguinal herni vakaların yaklaşık \% 1-3’ünde görülen bir durumdur. Çoğu asemptomatiktir, ancak dizüri, ani ve şiddetli idrar yapma isteği, noktüri ve hematüri gibi semptomlar da görülebilmektedir. Bilgisayarlı tomografi, herniasyon detaylarını detaylandırmak için en iyi görüntüleme seçeneğidir. $\mathrm{Bu}$ çalışma, inguinal mesane herniasyonu için acil hekimlerini bilinçlendirmeyi ve yanlış tanıyı önlemeyi amaçlamaktadır

Anahtar Kelimeler: Mesane herniasyonu, inguinal herni, inguinal şişlik

\section{INTRODUCTION}

Herniation of the urinary bladder is a rare, with reported incidence of about 1 to $3 \%$ cases of inguinal hernia. It occurs in $10 \%$ of men over 50 years old (1). Most are asymptomatic, but symptoms such as dysuria, frequency, urgency, nocturia and haematuria are also common. A typical symptom will be a reduction of hernia size after passing urine, and the ability to pass urine after pressing the hernia sac $(1,2)$. We are presenting a case with a inguinal bladder hernia (IBH) as a relatively rare entity, its unique presentation, for general awareness in hernia surgery. This study aims to raise awareness for emergency physicians for the IBH and to avoid misdiagnosis.

\section{CASE REPORT}

A 58-year-old man presented to hospital with 1-month history of left groin pain, intermittent dysuria and swelling. Four days prior to the swelling had become painful. He reported nausea, vomiting, difficulties with micturition and denied fever. Physical examination left direct inguinal hernia was present, which reduced on manipulation. His past medical history was unremarkable. On admission, his temperature was $37.2^{\circ} \mathrm{C}$, his heart rate was 82 beats/min, his respiratory rate was 16 breaths/ min and his blood pressure was $110 / 70 \mathrm{mmHg}$. The laboratory test results on admission were within the normal limits except microhematuria. Computed tomography (CT) revealed a left inguinal hernia with fluid density lesion continuous with left lateral bladder wall (Figure 1). Herniation of the bladder and continuity of the lesion with bladder wall was better demonstrated on sagittal and coronal reformatted images (Figure 2). No bowel/omentum was contained in the hernia. Bilateral kidneys were normal. Diagnosis of left IBH as

Illetişim: $\quad \begin{aligned} & \text { Dr. Cihan Bedel, Sağlık Bilimleri Üniversitesi, Antalya } \\ & \text { Eğitim ve Araştırma Hastanesi, Acil Tıp Kliniği, Antalya }\end{aligned}$
DOI:
$\quad \mathbf{1 0 . 1 7 5 1 7 / k s u t f d . 4 5 2 4 3 3}$

content was made. Patient was then referred to surgery department for further management.

Figure 1: Axial CT scan shows lateral deviation of the left lateral wall of the urinary bladder (arrow), which is pointing towards inguinal canal.

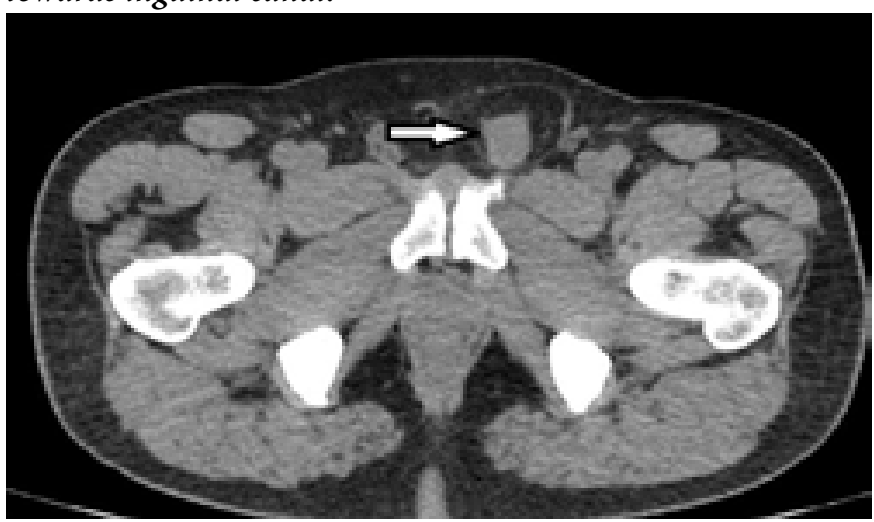

Figure 2: Sagittal reconstructed images better demonstrates the herniation of the bladder into the inguinal canal (arrow)

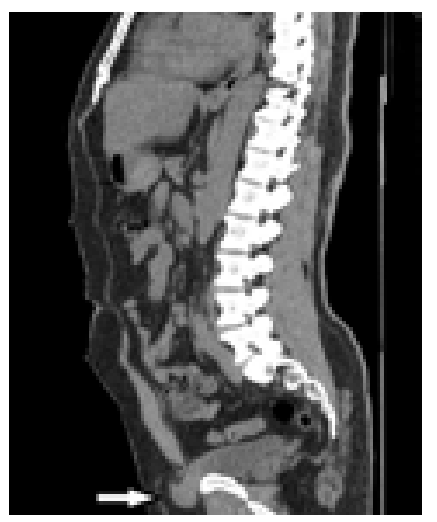

\section{DISCUSSION}

Urinary bladder can make herniation into the inguinal canal or scrotum. This can also be called a "scrotal cystocele". It is found in 1-3\% of inguinal hernias and and incidence is higher (about 10\%) in obese males, aged $\geq 50$ years (3). The ureters can
Tel

E-Posta : 05075641254

Geliş Tarihi : 09.08. 2018

Kabul Tarihi : 15. 10. 2018 
be found in the hernia. Intestinal structures can also be found at the hernia sac. Our case was an isolated bladder hernia. Ureters were clearly demonstrated and were found to be in normal position.

IBH is classified according to their relationship with the peritoneum as: a) paraperitoneal hernias , in which the extraperitoneal part of the hernia is located along the medial wall of the sac b) intraperitoneal hernia, in which herniated bladder is thus completely covered by peritoneum c) extraperitoneal hernia in which the bladder is not covered by peritoneum at all. However, the anatomical classification of the inguinal hernias (direct and indirect) can also be applied (1).

If the bladder outlet obstruction, intrapelvic mass, benign prostatic hypertrophy or any condition causing an increase in intraabdominal pressure, this can be ultimately lead to herniation of the urinary bladder. The urinary bladder can be quite asymptomatic, but some patients may even be seen with nonspecific symptoms such as dysuria, increased frequency of micturition, intermittent voiding, nocturia or even as pain at the site of hernia. Stagnation of urine in the bladder can also predispose to recurrent urinary tract infections. There are rare cases where bladder hernias presenting with renal failure has been reported $(4,5)$.

Different diagnostic methods can be used. Cystourethrography, ultrasonography, CT and magnetic resonance imaging are equally successful in establishing the diagnosis. However, CT is the most important diagnostic method because it can identify the content of hernia (bowel/omentum) and to exclude related complications such as strangulation and hydronephrosis. Surgical repair is the standard treatment for inguinal hernias involving the bladder (6-8).

As a result, although IBH is a rare condition, it should be considered in elderly male patients with inguinal swelling and voiding symptoms.

\section{REFERENCES}

1. Bacigalupo LE, Bertolotto M, Barbiera F, Pavlica P, Lagalla R, Mucelli RSP, et al. Imaging of urinary bladder hernias. Am J Roentgenol. 2005;184: 546-51.

2. Madani AH, Nikouei HM, Aval HB, Enshaei A, Asadollahzade A, Esmaeili S. Scrotal herniation of bladder: a case report. Iran J Med Sci. 2013; 38: 62.

3. Khan A, Beckley I, Dobbins B, Rogawski KM. Laparoscopic repair of massive inguinal hernia containing the urinary bladder. Urol Ann. 2014; 6:159.

4. Abaza R, Rashid MG, Sferra JJ. Obstructive uropathy from giant inguinal bladder and ureteral herniation. J Am Coll Surg. 2005; 201: 314.

5. Wagner AA, Arcand P, Bamberger MH. Acute renal failure resulting from huge inguinal bladder hernia. Urology. 2004; 64: 156-7.

6. Shelef I, Farber B, Hertzanu Y. Massive bladder hernia: ultrasonographic imaging in two cases. Br J Urol. 1998; 81: 492-3.

7. Andaç N, Baltaciođlu F, Tüney D, Çimşit NÇ, Ekinci $\mathrm{G}$, Biren T. Inguinoscrotal bladder herniation: is CT a useful tool in diagnosis? Clin Imag. 2002; 26: 347-8.

8. Bernaerts A, de Beeck BO, Hoekx L, Parizel P. Paraperitoneal indirect inguinal bladder hernia: $M R$ demonstration. Abdom Imaging. 2005; 30: 685-8. 